\title{
GAP-43 Expression in Primary Sensory Neurons following Central Axotomy
}

\author{
M. S. Chong, ${ }^{1}$ M. L. Reynolds, ${ }^{1}$ N. Irwin, ${ }^{2}$ R. E. Coggeshall, ${ }^{3}$ P. C. Emson, ${ }^{4}$ L. I. Benowitz, ${ }^{2}$ and C. J. Woolf ${ }^{1}$ \\ ${ }^{1}$ Department of Anatomy and Developmental Biology, University College London, London, WC1 E 6BT, United Kingdom, \\ 2Department of Neurosurgery, Children's Hospital, and Program in Neuroscience, Harvard Medical School, Boston, \\ Massachusetts 02115, ${ }^{3}$ Department of Anatomy, University of Texas Medical Branch, Galveston, Texas 77555, and ${ }^{4} \mathrm{MRC}$ \\ Group, Institute of Animal Physiology and Genetics Research, Baraham, Cambridge, United Kingdom
}

Primary sensory neurons are capable of successful regenerative growth in response to peripheral nerve but not dorsal root injury. The present study is concerned with the differential expression of the mRNA for GAP-43, a growth-associated protein, in these sensory neurons, in response to injury of their central or peripheral axonal branches. Peripheral axotomy resulted in an elevation in message detectable within $24 \mathrm{hr}$, using Northern blot and in situ hybridization, which was maintained for $30 \mathrm{~d}$, whereas dorsal root section produced no change except a transient and small increase if the axotomy was immediately adjacent to the dorsal root ganglia (DRG). Dorsal root section had no effect on GAP-43 mRNA levels in the dorsal horn or in neighboring intact DRG. It also failed to alter the laminar boundaries of the GAP-43 central terminal labeling produced by peripheral nerve section, even though vacant synaptic sites were produced in unstained laminae by this procedure. This indicates that the location of GAP-43 immunolabeling in the central terminals of primed sensory cells may not depend only on the location of vacant synaptic sites. We conclude that distinct control mechanisms regulate the response of DRG neurons to peripheral nerve and dorsal root injury, and these may be related both to the glial environment and the particular target influences exerted on the central and peripheral branches of the primary sensory neuron. Central denervation alone is insufficient to upregulate GAP-43 levels, and this may explain the relative absence of collateral sprouting after the production of central vacant synaptic sites. The failure of dorsal root section to increase GAP-43 expression may contribute to the poor regenerative response initiated by such lesions.

[Key words: GAP-43, regeneration, collateral sprouting, nerve injury, spinal cord, dorsal root ganglion]

GAP-43 is a membrane- and cytoskeletal-associated phosphoprotein (Zwiers et al., 1985; Benowitz and Routtenberg, 1987; Skene, 1989; Coggins and Zwiers, 1991) that is expressed at high

\footnotetext{
Received June 14, 1993; revised Dec. 6, 1993; accepted Jan 20, 1994.

We thank the Medical Research Council, International Spinal Research Trust, National Eye Institute (NIH) EY 05690, and the Boston Neurosurgical Foundation for financial support. C.J.W. is a recipient of a Bristol-Myers Squibb unrestricted pain research award.

Correspondence should be addressed to Professor Clifford J. Woolf, Department of Anatomy and Developmental Biology, University College London, Gower Street, London WCIE 6BT, UK.

Copyright (C) 1994 Society for Neuroscience $0270-6474 / 94 / 144375-10 \$ 05.00 / 0$
}

levels in neurons during development and concentrated in axonal growth cones (Jacobson et al., 1986; Kalil and Skene, 1986; Meiri et al., 1986; Skene et al., 1986; Karns et al., 1987; Biffo et al., 1990; Fitzgerald et al., 1991). Once innervation of targets is achieved, the levels of this protein decline in most parts of the nervous system. After neural injury in the adult, however, GAP-43 is reexpressed and rapidly transported along the axons of those neurons where there is successful regeneration (Skene and Willard, 1981; Benowitz and Lewis, 1983; Reh et al., 1987; Bisby, 1988; Tetzlaffet al., 1989; Van der Zee et al., 1989; Woolf et al., 1990). Where regeneration is abortive, there may be transient reexpression, but this is not sustained (Doster et al., 1991; Tetzlaff et al., 1991). The correlation between the presence of GAP-43 and the growth state of neurons has led to the use of this protein as a marker for axonal growth, and there is evidence from in vitro studies that would suggest that it is directly involved in such growth (Zuber et al., 1989; Yanker et al., 1990; Shea et al., 1991; Jap Tjoen San et al., 1992; Aigner and Caroni, 1993; Widemer and Caroni, 1993).

In the particular case of adult primary sensory neurons, peripheral axotomy results in successful reinnervation of peripheral targets, and this is associated with the reexpression of $\mathrm{GAP}$ 43 mRNA and protein in dorsal root ganglion (DRG) cells (Skene and Willard, 1981; Bisby, 1988; Hoffman, 1989; Van der Zcc et al., 1989; Verge et al., 1990a; Somervaille et al.. 1991; Chong et al., 1992; Wiese et al., 1992). In marked contrast, central axons of primary afferents have a limited regenerative capacity following dorsal root injury, which has commonly been explained in terms of a nonsupportive environment at the PNS/ CNS interface (Perkins et al., 1980; Carlstedt, 1985; Liuzzi and Lasek, 1987; Stensaas et al., 1987; Siegal et al., 1990; Liuzzi and Tedeschi, 1992).

We have investigated whether the relative failure of the central axons of primary sensory neurons to regenerate after dorsal root section is associated with a failure in GAP-43 upregulation. Four additional factors have been taken into account in the design of this study. First, previous reports have indicated that GAP43 reexpression is dependent on the site of axotomy relative to the soma (Doster et al., 1991; Tetzlaff et al., 1991). To investigate this, dorsal root sections have been performed both close to and distant from the ganglion. Second, while transected dorsal root axons do not reinnervate the dorsal horn, sprouting of the central terminals of dorsal root axons from adjacent intact dorsal roots and intrinsic dorsal horn neurons has been reported (Liu and Chambers, 1958; Goldberger and Murray, 1982; but see Rodin et al., 1983; McMahon and Kett-White, 1991). To study 


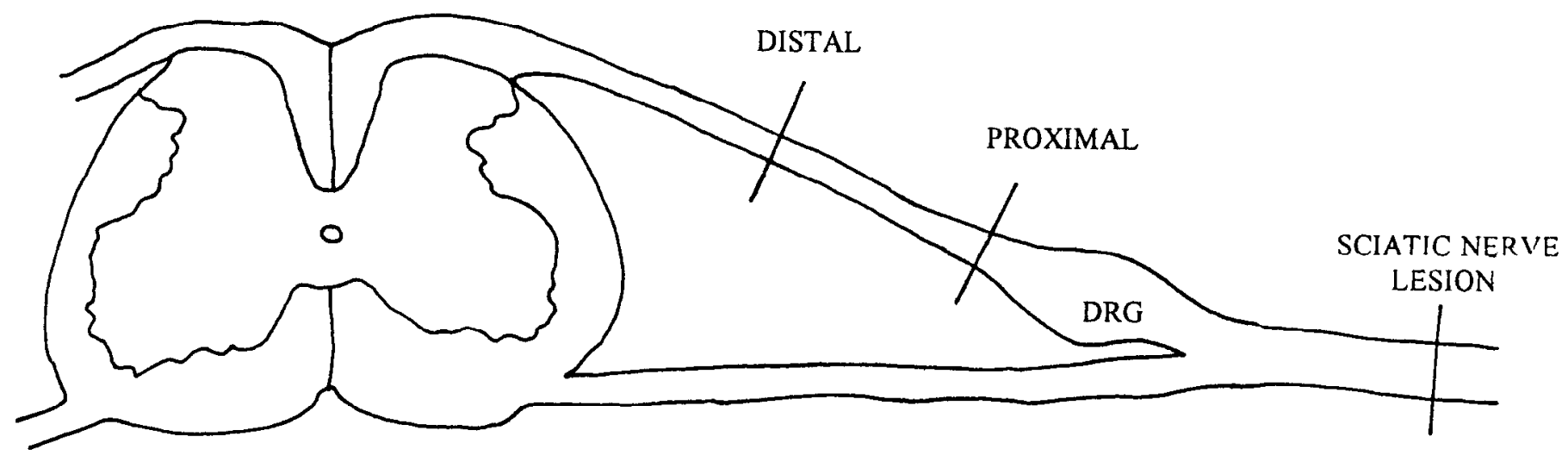

Figure 1. A diagram illustrating the surgical lesions performed: (1) dorsal root section adjacent to the entry of the dorsal root into the dorsal root ganglion in the intervertebral foramen (PROXIMAL), (2) dorsal root section midway between the DRG and the dorsal root entry zone in the spinal cord $(D I S T A L),(3)$ sciatic nerve section in the popliteal fossa.

whether central denervation alone is sufficient to induce G $\Lambda \mathrm{P}$ 43 upregulation in uninjured neighboring neurons, GAP-43 mRNA levels in the dorsal horn and in adjacent as well as lesioned ipsilateral and contralateral DRG were examined after dorsal root section. Third, we have asked whether there is an increase in GAP-43 protein levels in the dorsal horn after peripheral nerve injury (Woolf et al., 1990; Coggeshall et al., 1991; Knyihar-Csillik et al., 1992) or whether the results reflect the epitope specificity of the antibodies used (Schreyer and Skene, 1991). Finally, we have used immunohistochemical techniques to investigate whether the presence of vacant synaptic sites determines or influences the distribution of the GAP-43-labeled terminals in the spinal cord that results from a peripheral nerve injury by combining a nerve and dorsal root lesion. Together, these experiments are designed to investigate the nature of the signals responsible for controlling GAP-43 expression and presumably, therefore, axonal and synaptic growth in the first relay neurons of the somatosensory system.

\section{Materials and Methods}

Surgical procedures. Adult Sprague-Dawley rats (200-300 gm) of either sex were used. Under fentanyl/diazepam anesthesia, a left lumbar hemilaminectomy was performed and the L4 dorsal root sectioned midway between the L4 DRG and its entry into spinal cord, "distal rhizotomy" (Fig. 1). Animals were kept for $1 \mathrm{~d}(n=2), 3 \mathrm{~d}(n=2), 5 \mathrm{~d}(n=2), 7$ $\mathrm{d}(n=2)$, and $14 \mathrm{~d}(n=2)$ before being killed under terminal pentobarbitone anesthesia. Dorsal rhizotomy was also performed immediately adjacent to the L 4 intervertebral foramen, "proximal rhizotomy" in nine animals (Fig. 1), with survival of $1 \mathrm{~d}(n=2), 3 \mathrm{~d}(n=2) 5 \mathrm{~d}$ $(n=2), 7 \mathrm{~d}(n=2)$, and 4 weeks $(n=1)$ postoperatively. Section of the $\mathrm{L} 3, \mathrm{~L} 4$, and $\mathrm{L} 5$ dorsal roots was performed in 11 other rats and the animals permitted to recover for $10 \mathrm{~d}$.

In 31 animals the left sciatic nerve was exposed in the popliteal fossa under fentanyl/diazepam anesthesia and crushed with a pair of smooth tipped forceps until an area of complete translucency was produced. After recovery for $1 \mathrm{~d}(n=10), 7 \mathrm{~d}(n=1), 10 \mathrm{~d}(n=9), 14 \mathrm{~d}(n=2)$, or $30 \mathrm{~d}(n=9)$, the animals were killed under terminal pentobarbitone anesthesia. In four animals the sciatic nerve was sectioned, rather than crushed, and $2 \mathrm{~d}$ later the left L4 dorsal root sectioned. The animals were then killed at $14 \mathrm{~d}(n=2)$ or $30 \mathrm{~d}(n=2)$.

Tissue preparation. Tissue was used for one of three procedures: Northern blot analysis or in situ hybridization for the detection of GAP43 mRNA, and GAP-43 immunohistochemistry to detect levels and distribution of the protein. For the first two, the L3-L5 segments of the spinal cord and ipsilateral and contralateral L3-L5 DRGs were removed fresh under terminal anesthesia. For immunohistochemistry, the animals were perfused with saline followed by $4 \%$ paraformaldehyde in $0.1 \mathrm{~m}$ phosphate buffer at $\mathrm{pH}$ 7.4. The third, fourth, and fifth lumbar segments, defined by the point of entrance of their dorsal roots into the dorsal horn, were then removed, postfixed for $6 \mathrm{hr}$, and then immersed in $20-30 \%$ sucrose in phosphate buffer $\left(\mathrm{pH} 7.4,4^{\circ} \mathrm{C}\right)$ overnight.

Northern blot analysis. The L3, L4, and L5 DRG ipsi- and contralateral to either a sciatic nerve section or the dorsal root sections were removed as was the spinal cord, which was divided into four quadrants: dorsal and ventral halves, ipsi- and contralateral to the nerve/dorsal root section. For each time point for each surgical procedure tissue from three or four animals was frozen on dry ice, pooled, and stored at $-70^{\circ} \mathrm{C}$. Total RNA was extracted by homogenization in $4 \mathrm{M}$ guanidium thiocyanate buffer (Chirgwin et al., 1979). RNA (10 $\mu \mathrm{g} / \mathrm{sample}$ ) was separated on formaldehyde-agarose gels, transferred to nylon membranes, and hybridized with GA1 1B, a 1.1 kilobase cDNA to GAP-43 (Neve et al., 1987). Another probe used as a control for loading was for glyceraldehyde 3-phosphate dehydrogenase (G3PD), a "housekeeping gene." The cDNAs were labeled with ${ }^{32} \mathrm{P}-\mathrm{CTP}$ using the random priming method. Washed blots were exposed to Kodak X-Omat AR film (1-33 d).

In situ hybridization. All tissue was embedded in Tissue-Tek and freshly frozen in liquid nitrogen. Thick sections $(20 \mu \mathrm{m})$ were cut on a cryostat, mounted on chrome-alum gelatinized slides, and after rapid drying in cool air, processed for in situ hybridization for GAP-43 mRNA using an alkaline phosphatase-linked cDNA probe (described in detail in Chong et al., 1992). An alkaline phosphatase-linked antisense oligodeoxynucleotide antisense probe (39-mer corresponding to positions 119-157 of the rat GAP-43 mRNA) was used. Bound probe was visualized by the color reaction of alkaline phosphatase on the substrates nitroblue tetrazolium and 5-bromo-4-chloro-3-indolyl-phosphate.

Staining was eliminated if sections were pretreated with ribonuclease $A$ or if a 100-fold excess unlabeled oligonucleotide probe was included in the hybridization mix. No staining was seen if the probe was omitted from the hybridization solution.

Cell counting was done with the aid of a computerized image analysis system (See-Scan, Cambridge, UK; described in Chong et al., 1992). This permitted both the analysis of the presence of positive cells by relative intensity measurements and a semiautomation of the dissector counting technique. This is a stereological method where systematic sampling of tissue with a constant separation $(k)$ is done (for a review, see Gundersen et al., 1988; Coggeshall, 1992). The whole tissue was sectioned and the total number of sections counted. Sections were then chosen as in a standard stereological paradigm, with a section separation $k$, with the first section being chosen with a random number generator. The area of each chosen section was then measured, and the total volume of the tissue calculated. Adjacent pairs of sections were then examined and one was designated the reference section. Stained neuronal profiles seen in the reference section but not in the look-up section were counted. The number of counts ("tops") in the volume of the sampled tissue yielded the number of neurons per unit volume ( $N_{v}$, numerical density).

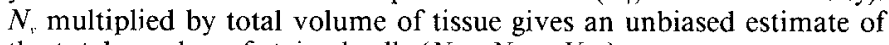
the total number of stained cells $\left(N=N_{\mathrm{r}} \times V_{\mathrm{rcr}}\right)$.

Immunohistochemistry. Frozen sections $(50 \mu \mathrm{m})$ were cut and stained free floating as described before (Woolf et al., 1990) using one of three GAP-43 antisera: (1) $\alpha$ GAP-43 Ab I, a polyclonal rabbit antiserum to a $\beta$-galactosidase/GAP-43 fusion protein (Curtis et al., 1991), a gift of 
Control

\section{Unoperated}

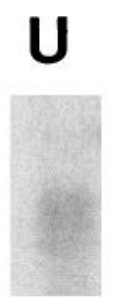

Sciatic Nerve

$$
\text { Crush }
$$

$I_{1} C_{1} I_{10} C_{10} I_{30} C_{30}$

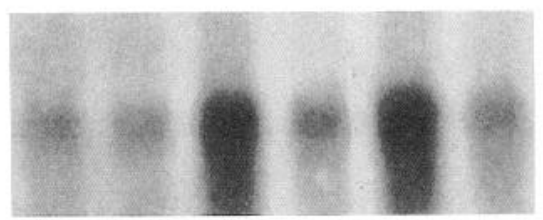

Dorsal

Rhizotomy

$I_{10} C_{10}$

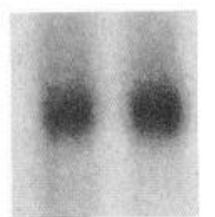

\section{GAP43}
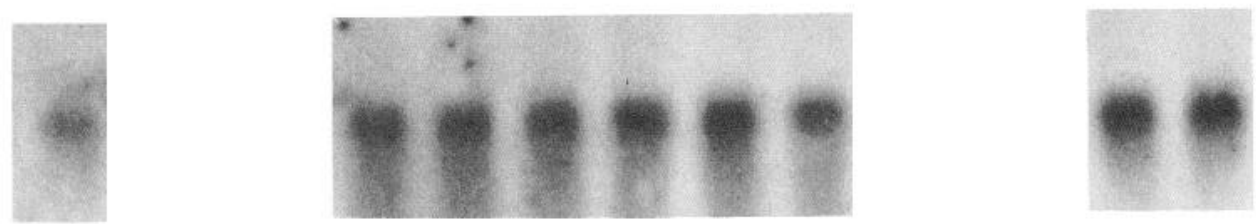

\section{G3PD}

Figure 2. Northern blots for GAP-43 and G3PD mRNA in L3, L4, and L5 pooled (three or four animals) dorsal root ganglia from naive (control, unoperated; $U$ ) animals, 1,10 , and $30 \mathrm{~d}$ following a sciatic nerve crush and $10 \mathrm{~d}$ following a distal dorsal root section $(I$, ipsi-, and $C$, contralateral ganglia).

R. Curtis, Regeneron, NY, diluted 1:2000-40,000; (2) $\alpha$ GAP-43 Ab II, a mouse monoclonal antibody 9-1E12 raised against neonatal rat brain GAP-43 (Boehringer-Mannheim; Schreyer and Skene, 1991) diluted 1:1000-40,000; and (3) $\alpha \mathrm{GAP}-43 \mathrm{Ab}$ III, a polyclonal sheep antiserum to rat brain GAP-43 obtained from neonatal rat cortex (1:1000-6000) (Benowitz et al., 1988). After preincubation with appropriate normal serum for $1-2 \mathrm{hr}$, sections were incubated for $24 \mathrm{hr}$ at $4^{\circ} \mathrm{C}$ with one of the three antibodies. Incubation times were kept constant for each experiment where staining patterns of the three antibodies were compared. Dilutions were made in PBS containing $1 \%$ appropriate normal serum and $0.4 \%$ Triton $X-100$, plus $0.01 \%$ azide. After washing with several changes of PBS, sections were incubated with the appropriate biotinylated IgG (Vector Laboratories) diluted $1: 150$ or $1: 250$ for $1-2 \mathrm{hr}$, followed by Vectastain $\mathrm{ABC}$ reagent. The sections were then incubated in a $0.05 \%$ solution of $3,3^{\prime}$-diaminobenzidine tetrahydrochloride in Tris buffer plus $0.01 \% \mathrm{H}_{2} \mathrm{O}_{2}$ for $10 \mathrm{~min}$. Following several washes with water, the sections were mounted on gelatinized slides, dehydrated, and coverslipped with DPX mountant. Substitution of primary antisera and of biotinylated IgGs by either nonimmune serum or PBS was performed for all the sets of tissue, and in each case, these controls gave negative results.

\section{Results}

Northern blot analysis

Sciatic nerve crush resulted in a substantial elevation in GAP43 mRNA in the ipsilateral L3, L4, and L5 ganglia that was detectable at $1 \mathrm{~d}$, and reached a peak, with up to a sixfold increase, between 4 and $10 \mathrm{~d}$ postinjury. This elevation persisted, at slightly reduced levels, at $30 \mathrm{~d}$ postinjury (Fig. 2). No change was detected in the contralateral DRGs. This result was duplicated in three independent series. In spinal cords tested 10 $\mathrm{d}$ after the sciatic nerve crush, an elevation in GAP-43 mRNA was only found in the ipsilateral ventral quadrant, the site of the axotomized motoneurons. The ipsilateral and contralateral dorsal quadrants had identical levels of GAP-43 mRNA.

A distal dorsal root section resulted in no detectable alteration in GAP-43 mRNA levels in the affected ganglia or in the ipsilateral dorsal or ventral quadrants of the spinal cord $10 \mathrm{~d}$ after central axotomy; this finding was likewise repeated in three independent series of animals, with results evaluated by densitometry and levels of signal normalized for loading (Fig. 2).

\section{In situ hybridization}

Peripheral axotomy resulted in an increase in the number of GAP-43 mRNA-containing L4 DRG cells as described previously (Hoffman, 1989; Verge et al., 1990a; Chong et al., 1992), with a threefold increase $1 \mathrm{~d}$ after the lesion and a further increase at 1 week (Figs. 3,4). No upregulation of GAP-43 mRNA expression was detected in the L4 DRG after a distal dorsal rhizotomy performed. At all times tested between 1 and $14 \mathrm{~d}$ after operation, the numbers of GAP-43 mRNA-positive cells remaining similar to those present in naive unoperated animals or in DRGs contralateral to a peripheral nerve injury (Figs. 3, 4; Table 1). After a proximal rhizotomy, a small elevation in the number of positive DRG cells occurred at 1 and $3 \mathrm{~d}$ postinjury, but by $7 \mathrm{~d}$ the levels had fallen to control values (Figs. 3 , 4; Table 1). Intact dorsal root ganglia one segment above or below a lesioned root showed no significant upregulation of GAP-43 mRNA. One and two weeks after an L4 dorsal rhizotomy, the number of positively labeled cells in the L3 and L5 dorsal root ganglia did not differ from that present in the contralateral side (Table 2). 


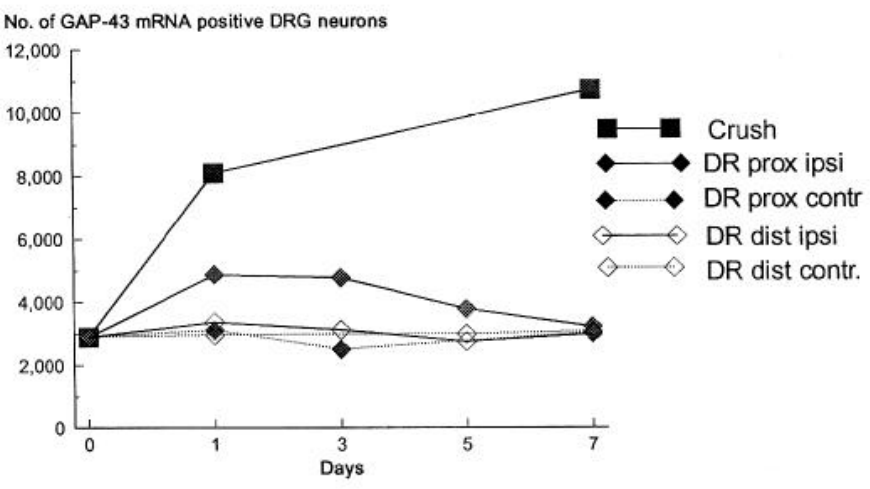

Figure 3. Alterations in the numbers of GAP-43 mRNA-positive L4 DRG neurons obtained after sciatic nerve crush or a proximal or distal L4 rhizotomy. Each value is the mean of the counts from two ganglia (see Table 1). The results at time 0 represent values from naive animals $(n=4)$.

In the spinal cord, no staining for GAP-43 mRNA was visible in dorsal horn neurons after a distal dorsal rhizotomy or peripheral nerve section, although the latter lesion resulted in the appearance of GAP-43 mRNA in axotomized motor neurons. The only change seen in the spinal cord after dorsal root lesions was a reduction in size of the ipsilateral dorsal funiculus (Fig. 5).
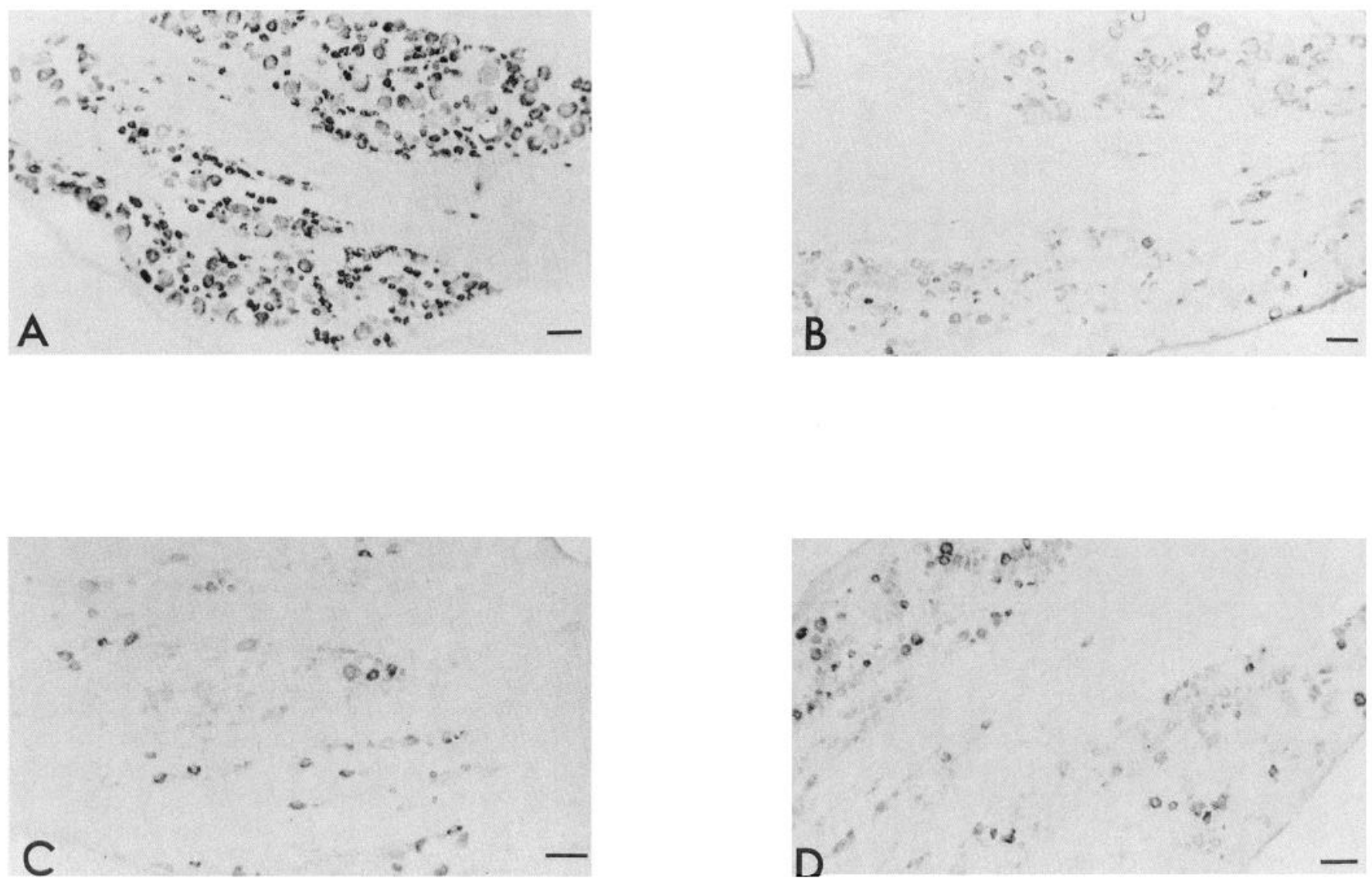

Figure 4. In situ hybridization for GAP-43 mRNA in sections cut through an ipsilateral $(A)$ and contralateral L4 DRG $(B) 7 \mathrm{~d}$ after a sciatic nerve crush injury. $C$ shows the level of GAP-43 mRNA in a L4 DRG following a distal L4 rhizotomy 2 weeks earlier. $D$ is a section through an L4 ganglion following a proximal rhizotomy $3 \mathrm{~d}$ earlier. Scale bars, $100 \mu \mathrm{m}$.

\section{GAP-43 immunohistochemistry}

GAP-43 is posttranslationally modified by phosphorylation, acylation, and ribosylation (Skene, 1989; Coggins and Zwiers, 1991; Coggins et al., 1993) and modified forms could conceivably be recognized differentially by antibodies directed against distinct epitopes, which could result in variations in the staining patterns obtained in the spinal cord after nerve injury (Schreyer and Skene, 1991). In order to investigate this issue, three quite different anti-GAP-43 antibodies were used to survey both the pattern of staining in the normal spinal cord and the effects of a peripheral axotomy. These were $\mathrm{Ab} \mathrm{I}$, a polyclonal rabbit antiserum to a $\beta$-galactosidase/GAP-43 fusion protein (Curtis et al., 1991); Ab II, a mouse monoclonal antibody (9-1E12) that is insensitive to posttranslational modification (Schreyer and Skene, 1991; obtained from Boehringer-Mannheim); and Ab III, a polyclonal $\alpha$ GAP-43 IgG fraction raised in sheep against rat GAP-43 protein extracted from neonatal cortex (Benowitz et al., 1988). Different intensities of staining of the dorsal horn in control animals were produced by the antibodies at different titers (with $\mathrm{Ab}$ I and $\mathrm{Ab}$ II $>\mathrm{Ab}$ III at the same nominal concentration). With appropriate dilutions, however, the staining patterns became indistinguishable: at relatively low titers, all revealed a low level of staining in the white matter, except in the corticospinal tract, and higher levels in the gray matter, particularly in the superficial laminae of the dorsal horn; at higher titers, all began to produce heavier staining in the gray 
Table 1. Dissector counts of LA DRG after dorsal rhizotomy or sciatic nerve crush

\begin{tabular}{|c|c|c|c|}
\hline Animal & Survival time & Ipsi. count & $\begin{array}{l}\text { Contra. } \\
\text { count }\end{array}$ \\
\hline \multicolumn{4}{|c|}{ Dorsal rhizotomy distally } \\
\hline 1 & $1 \mathrm{~d}$ & 3268 & 2962 \\
\hline 2 & $1 \mathrm{~d}$ & 3488 & \\
\hline 3 & $3 \mathrm{~d}$ & 2847 & \\
\hline 4 & $3 \mathrm{~d}$ & 3318 & \\
\hline 5 & $5 \mathrm{~d}$ & 2749 & 2988 \\
\hline 6 & $5 \mathrm{~d}$ & 3143 & \\
\hline 7 & $7 \mathrm{~d}$ & 2822 & 3073 \\
\hline 8 & $7 \mathrm{~d}$ & 3286 & \\
\hline 9 & $14 \mathrm{~d}$ & 2670 & 2473 \\
\hline \multicolumn{4}{|c|}{ Dorsal rhizotomy proximally (close to DRG) } \\
\hline 1 & $1 \mathrm{~d}$ & 4626 & \\
\hline 2 & $1 \mathrm{~d}$ & 5226 & 3110 \\
\hline 3 & $3 \mathrm{~d}$ & 4280 & 2506 \\
\hline 4 & $3 \mathrm{~d}$ & 5217 & \\
\hline 5 & $5 \mathrm{~d}$ & 3552 & \\
\hline 6 & $5 \mathrm{~d}$ & 3846 & \\
\hline 7 & $7 \mathrm{~d}$ & 2692 & 3030 \\
\hline 8 & $7 \mathrm{~d}$ & 3473 & \\
\hline 9 & $28 \mathrm{~d}$ & 2706 & 2542 \\
\hline \multicolumn{4}{|c|}{ Sciatic nerve crush } \\
\hline 1 & $1 \mathrm{~d}$ & 8107 & 2579 \\
\hline 2 & $7 \mathrm{~d}$ & 10725 & \\
\hline
\end{tabular}

matter (Fig. 6). Following a sciatic nerve lesion $14 \mathrm{~d}$ earlier, identical staining patterns were achieved for each antibody, but at different titers, with intense label in laminae I and II in the ipsilateral sciatic nerve terminal territory and a few sparse projections into lamina III (Fig. 6). For each antibody a titer could be found where the "background" level was very low/absent while still clearly revealing the label resulting from the nerve injury (Fig. 6). The increase in the concentration of the antibodies required to produce a level of staining where the "background" began to obscure the label in the axotomized central terminals, differed for each antibody with a 20 -fold increase for $\mathrm{Ab}$ I, a 40-fold increase for Ab II, and a sixfold increase for Ab III. At high titers, label could be detected in the ipsilateral dorsal columns, particularly for Ab I.

Distal dorsal root section did not result in elevated GAP-43 immunostaining in the dorsal horn (Fig. 7A). Intense label was present in the degenerated root at the dorsal root entry zone, which is likely to be of Schwann cell origin (Curtis et al., 1992; Woolf et al., 1992b). Section of the L4 dorsal root, when combined with peripheral nerve injury, eliminated staining in areas where the rhizotomized afferents terminate (Fig. 7B), but in adjacent areas where the afferent terminals originate from neighboring intact roots, the laminar distribution of staining was unchanged. Because the central terminals of afferents from different roots overlap, it was difficult to evaluate if any spread of GAP-43 had occurred from the L3 and L5 root terminal zones to the L4 zone within laminae I and II.

\section{Discussion}

Primary sensory neurons possess two axons that are different in several major respects. The central axon is smaller (Suh et
Table 2. Dissector counts of L3 and L5 DRG cells positively labeled for GAP-43 mRNA after LA dorsal rhizotomy

\begin{tabular}{lll} 
& \multicolumn{1}{c}{ Ipsilateral } & Contralateral \\
\hline 1 Week dorsal rhizotomy & \\
L3 & 1808 & 2123 \\
L5 & 2390 & 2250 \\
2 Weeks dorsal rhizotomy & \\
L3 $\quad 1984$ & 2114 \\
L5 & 2951 & 2826 \\
\hline
\end{tabular}

Normal unoperated L4 DRG count, 2740-3350.

al., 1984), has a slower conduction velocity (Czeh et al., 1977) and rate of axonal transport (Wujek and Lasek, 1983), and is associated with both Schwann cells and CNS glia, whereas the peripheral process is associated with Schwann cells only, and its targets are very different from those of the peripheral process. Another difference is that regeneration is generally successful after peripheral axon transection but much slower and less suc-
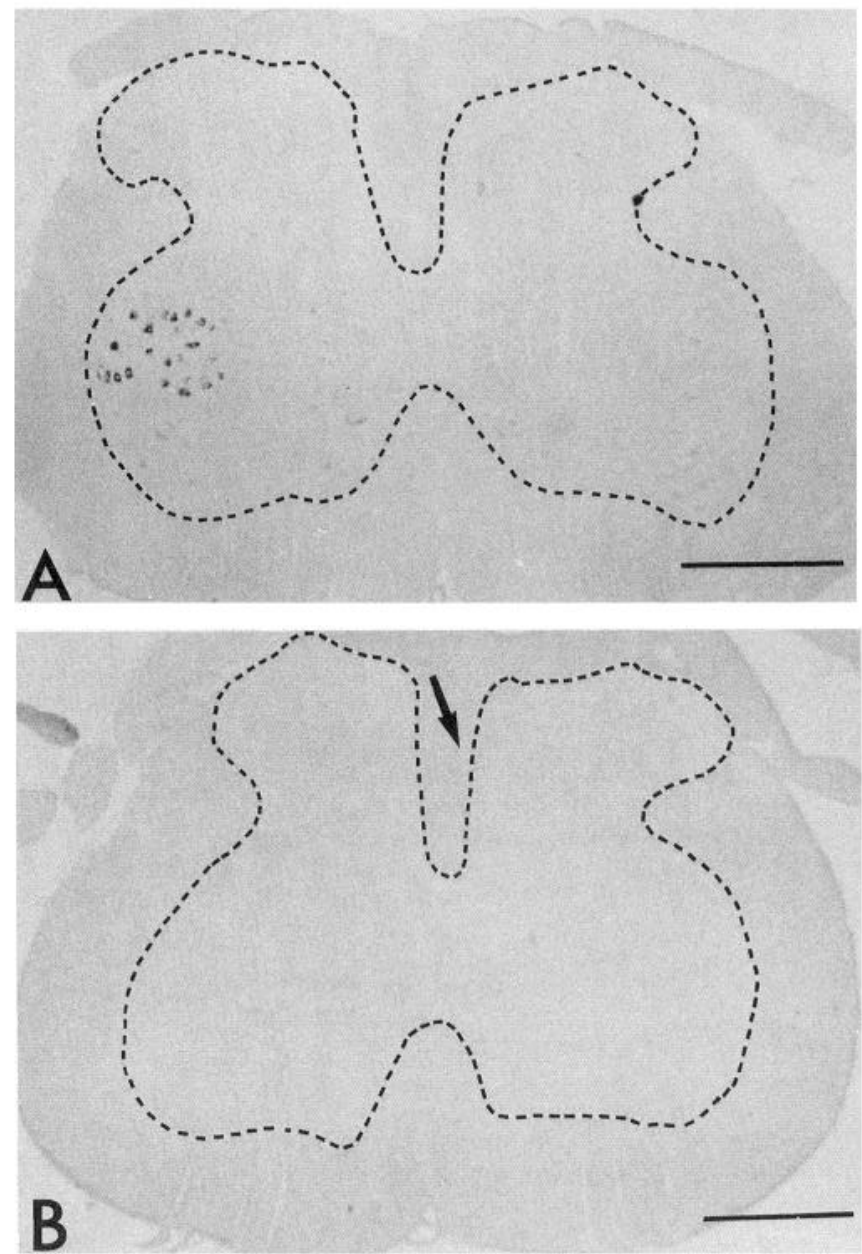

Figure 5. Transverse sections through L4 spinal cord 1 week after sciatic nerve section $(A)$ or a distal L4 dorsal rhizotomy $(B)$ stained for GAP-43 mRNA by in situ hybridization. Note the absence of GAP-43 mRNA signal in the dorsal horn in both cases and the labeled motor neurons after the peripheral nerve crush lesion. The arrow indicates the reduction in the size of the dorsal column on the operated side. Scale bars, $500 \mu \mathrm{m}$. 


\section{IPSI}
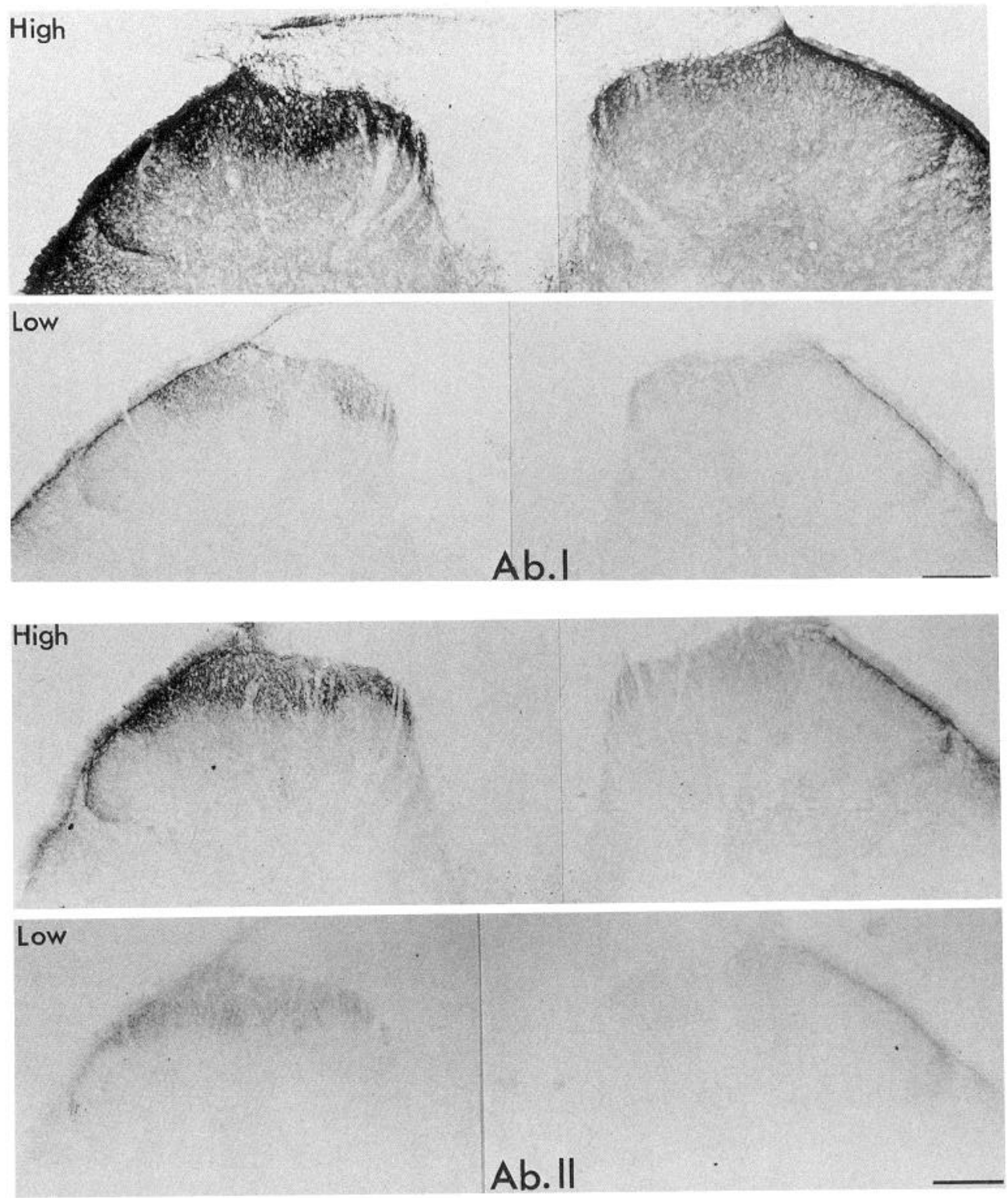

Figure 6. Transverse sections through an L4 spinal cord 2 weeks after sciatic nerve section stained with three different anti-GAP-43 antibodies. $A b . I$, a polyclonal antiserum to a $\beta$-galactosidase/GAP-43 fusion protein (Curtis et al., 1991); $A b . I I$, a mouse monoclonal (9-1E12, Schreyer and Skene, 1991); and $A b$. III, a polyclonal antiserum to rat GAP-43 (Benowitz et al., 1988). Examples are shown for each antibody of the staining pattern produced by a high and a low titers (Ab I: high 1:2000, low $1: 40,000 ; \mathrm{Ab}$ II: high 1:1000, low $1: 40,000$; Ab III: high 1:1000, low $1: 6000$ ). Note that at the low titer in all cases, staining is present ipsilateral to the nerve injury $(I P S I)$ at higher levels than the background and that the distribution and pattern of staining is identical for all antibodies. The staining shown in the contralateral dorsal horn (CONTRA) is identical that found in naive animals (not shown).
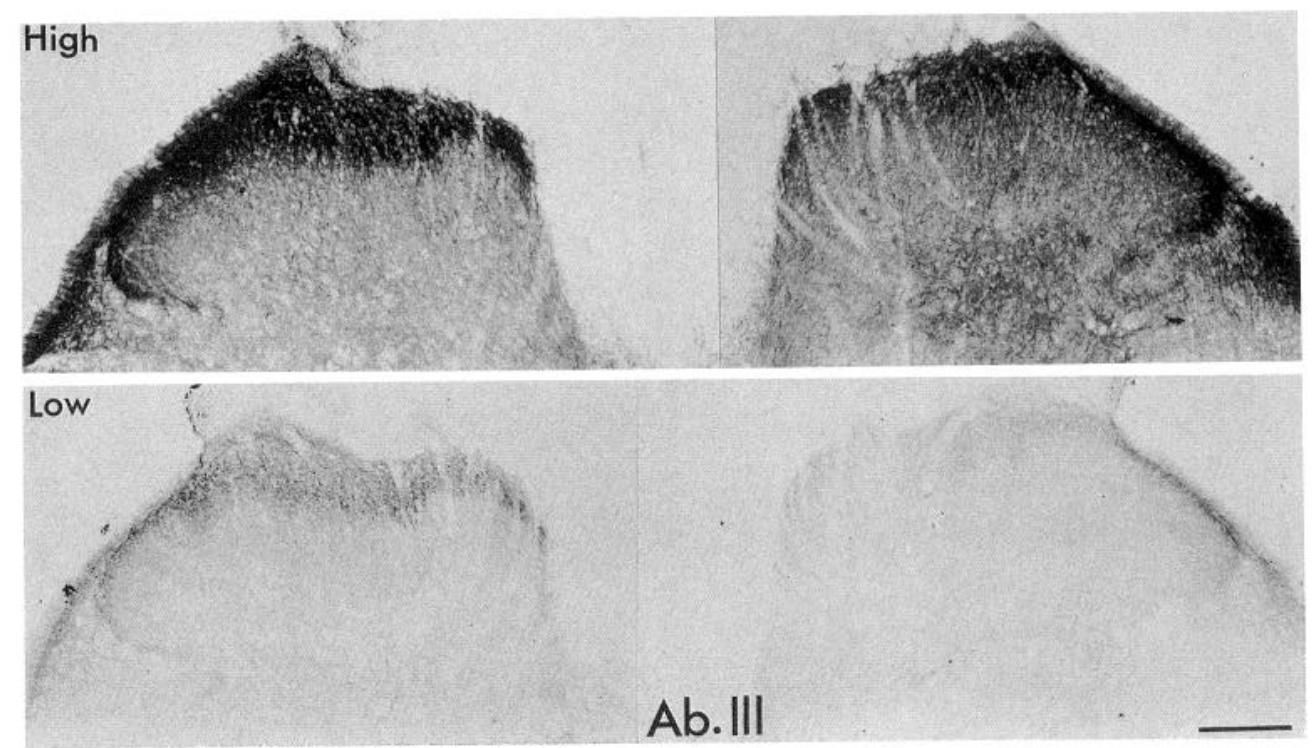

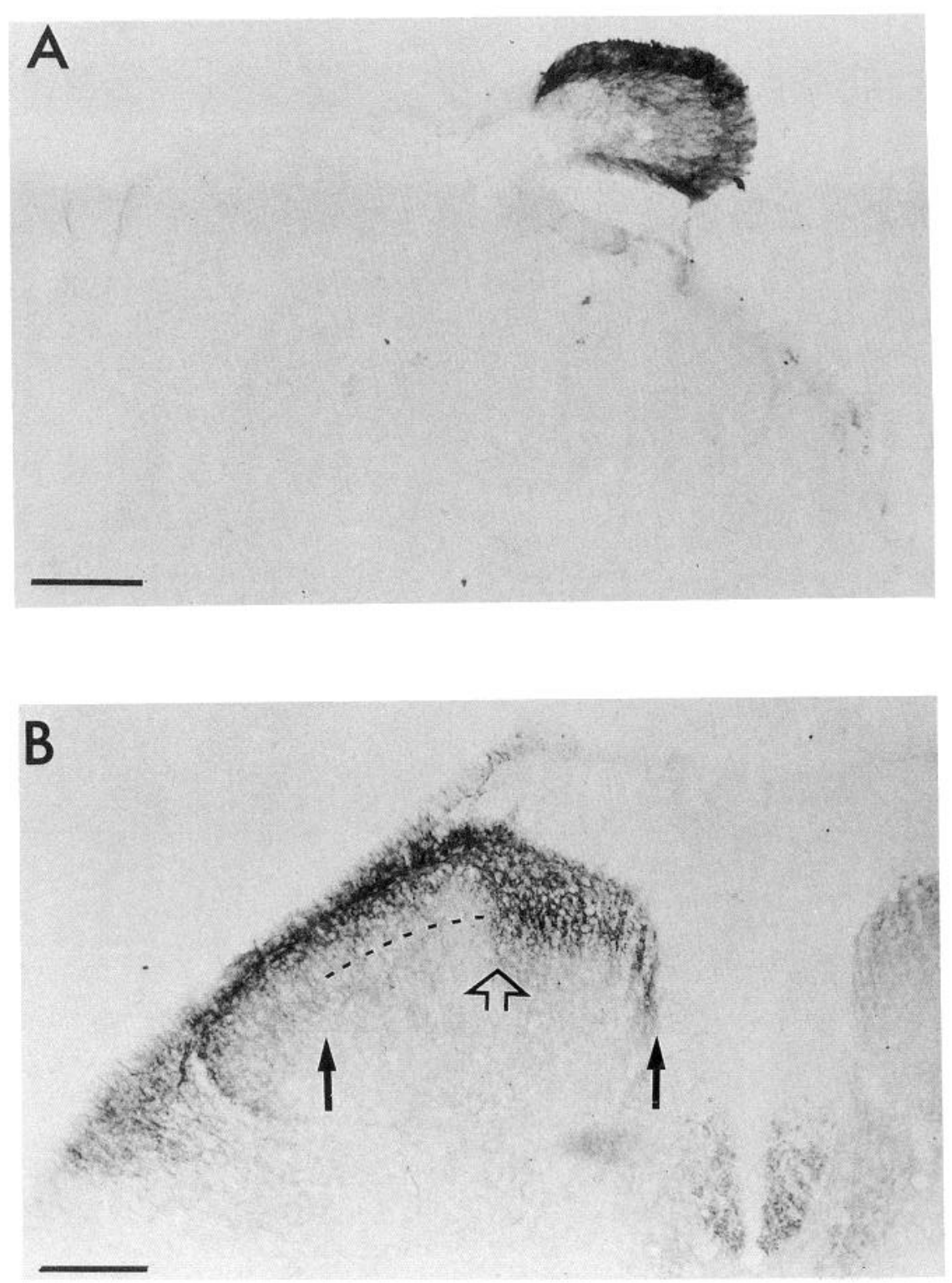

Figure 7. A, A transverse section through the L4 dorsal horn stained for GAP-43 with Ab III $10 \mathrm{~d}$ following a distal L4 dorsal root section. Note the absence of any immunoreactivity in the dorsal horn but the presence of some label in the distal dorsal root, presumably in denervated Schwann cells. $B, \mathrm{~A}$ transverse section through the L5 dorsal horn $10 \mathrm{~d}$ after a sciatic nerve section that was followed $2 \mathrm{~d}$ later by an L4 dorsal root section. The dorsal root section has curtailed the expected mediolateral distribution of GAP-43 immunoreactivity in lamina II produced by the sciatic nerve lesion, which normally encompasses the medial twothirds of the dorsal horn (illustrated by the two solid arrows; see also Fig. 5), but it has not altered the dorsoventral spread of the label, which remains largely restricted to the superficial laminae of the dorsal horn. The broken line in lamina II illustrates the region that does not contain the expected label and the open arrow shows the clear cutoff between the normally innervated medial area of the dorsal horn and the denervated region lateral to it. cessful after central axon transection (Wujek and Lasek, 1983; Oblinger and Lasek, 1984; Anderson et al., 1992a). Responses of the DRG cell body to transection of the peripheral as opposed to the central process are also generally different. Dorsal rhizotomy does not result in chromatolysis, whereas peripheral transection does (Liebermann, 1971). Successful regeneration may require the induction of a growth capacity in the injured cell, and the chromatolytic response may be a morphological sign of this. Peripheral nerve injury results in a stereotyped pattern of changes in growth-associated or cytoskeletal proteins in DRG neurons such as elevations in GAP-43 and $\alpha-1$ tubulin and a decrease in neurofilament levels (Hoffmann, 1989; Miller et al., 1989; Wong and Oblinger, 1990; Gold et al., 1991). Whether dorsal root and peripheral nerve section results in similar changes in $\alpha-1$ tubulin and neurofilament levels remains controversial (Greenberg and Lasek, 1988; Verge et al., 1990b; Wong and Oblinger, 1990; Ernfors et al., 1993), but GAP-43 is clearly not elevated by central axotomy. This failure may be an important reason for the relatively poor rate of regeneration after dorsal root injury (Anderson et al., 1992b). The growth of the central axon into peripheral nerve grafts is greatly accelerated and the number of growing axons substantially increased if the dorsal root injury is accompanied by a peripheral injury, which increases GAP-43 levels (Richardson and Issa, 1984; Richardson and Verge, 1987; Anderson et al., 1992a; but see Oblinger and Lasek, 1984).

The nonuniformity of the responses to transection of the central and peripheral primary afferent axon implies different signals, some of which are presumably common to both and some of which are unique to the peripheral nerve injury. Since effectively all DRG neurons upregulate GAP-43 after peripheral injury (Hoffmann, 1989; Verge et al., 1990a; Sommervaille et al., 1991; Chong et al., 1992; Wiese et al., 1992), the signal for its upregulation is likely to be common to all cells. This would seem to exclude NGF, a lack of which has been proposed as the retrograde signal for cell death, cell atrophy, and the reduction in substance P (Fitzgerald et al., 1985; Rich et al., 1987; Verge et al., 1990b; Gold et al., 1991; Wong and Oblinger, 1991), 
because not all DRG cells possess the high-affinity NGF receptor or express trkA mRNA (Verge et al. 1990a, 1993; Ernfors et al., 1993). In accord with this, NGF does not change the effect of axotomy on GAP-43 expression in vivo (Verge et al., 1990a) or in vitro (Hu-Tsai et al., 1992).

Central axotomy does not upregulate GAP-43 mRNA in primary afferent neurons except transiently if the axotomy is performed ncar the ganglion. This is probably the result of an inflammatory infiltrate around the ganglion generated by the surgery since GAP-43 has been shown to be upregulated following inflammation in the vicinity of the ganglion ( $\mathrm{Lu}$ and Richardson, 1992). Other studies have reported GAP-43 reexpression when axotomy is performed close to cell bodies (Doster et al., 1991; Tetzlaff et al., 1991), although in the latter case, both lesions were far enough from the cell bodies to eliminate inflammation as a factor.

Central denervation also failed to upregulate GAP-43 in neighboring intact DRG cells or in dorsal horn neurons. Thus, the signal(s) that controls GAP-43 levels is not related to either axonal injury or disruption of target contact alone, and denervation alone is not a sufficient trigger for inducing GAP-43 upregulation. This may have implications in terms of the capacity of the central terminals of uninjured primary sensory neurons to sprout into neighboring denervated areas (Liu and Chambers, 1958; Goldberger and Murray, 1982; Rodin et al., 1983; Pubols and Bowen, 1988; LaMotte et al., 1989; McMahon and Kett-White, 1991). GAP-43 immunoreactivity correlates with the induction of collateral sprouting following denervation in the hippocampus and at the motor end-plate (Benowitz et al., 1990; Lin et al., 1992; Mehta et al., 1993), but dorsal root section does not increase GAP-43 immunoreactivity in the dorsal horn.

Central terminal sprouting is a different form of growth from collateral sprouting, involving growth of the intact central branches of primary sensory neurons seen after injury to their peripheral branches (Woolf et al., 1992a). This is possibly the result of the peripheral lesion-induced increase in GAP-43 expression in the DRG and the transport of this compound to the central terminals (Woolf et al., 1990), where it may enable growth. This view has been challenged by the suggestion that the appearance of lesion-induced GAP-43 immunoreactivity in the dorsal horn (Woolf et al., 1990) reflects posttranslational modifications of preexisting GAP-43 rather than the transport of newly formed GAP-43 (Schreyer and Skene, 1991). The evidence was that a monoclonal antibody that recognized epitopes on posttranslationally unmodified and modified forms of GAP43 gave a generalized staining in the dorsal horn of normal animals with no detectable increase after a nerve lesion, whereas antibodies that only recognized epitopes that may arise by posttranslational processing gave little staining in the normal and a marked increase after nerve transection. We have now made a direct comparison of this antibody (9-1E12; Schreyer and Skene, 1991 ) with the antibody used in the original study (Woolf et al., 1990 ) and another polyclonal GAP-43 antibody. When diluted to appropriate titers, all three antibodies produce indistinguishable staining patterns in both naive and nerve injured animals, namely, little staining in the normal and a marked increase after nerve lesion. When the titer was increased, however, all three antibodies produced the generalized staining reported by Schreyer and Skene (1991). It is clear, therefore, that background levels of GAP -43 in the normal dorsal horn are much lower than those in the central terminals of peripherally axotomized afferents.
Another question is why GAP-43 is not found in the deep dorsal horn after nerve injury (Woolf et al., 1990). Large DRG cells whose processes end here have a faint but positive immunoreactivity for GAP-43 (Sommervaille et al., 1991). In the periphery, however, only unmyelinated axons stain for GAP43 during regenerative growth (Hall et al., 1992). Large sensory and motor neurons do increase GAP-43 mRNA substantially after injury (Chong et al., 1992; Wiese et al., 1992), and myelinated motor axons reinnervating motor end-plates are immunoreactive (Woolf et al., 1992b). Why, then, is there no label in the deep dorsal horn after a nerve lesion, particularly since it has been shown that large fibers grow into superficial laminae following nerve lesion (Woolf et al., 1992a; Shortland and Woolf, 1993)? The most likely possibility is that GAP-43 is concentrated only in the parts of the axons that are growing, which would imply that only the unmyelinated sprouts and growth cones from the large fibers are GAP-43 immunoreactive. If this is the case, the next question is why do large fibers grow into lamina II following injury? Our hypothesis has been that large A fibers are primed for growth by peripheral axotomy (Woolf et al., 1992a), which simultaneously frees up some synaptic space by inducing atrophy of $\mathrm{C}$ fiber terminals (Castro-Lopes et al., 1991), and that it is the combination of priming and an "open" synaptic field that results in sprouting. The failure to induce detectable staining in the deep dorsal horn following a combination of a peripheral nerve and dorsal root lesion, which would cause synaptic loss in all dorsal horn laminae (Chung et al., 1989), indicates that some factor or factors other than priming and central denervation must play a role in the central sprouting. This might be either a relative absence of growth inhibitory molecules, such as those present on oligodendrocytes (Schwab, 1990), or a permissive extracellular matrix (Fawcett, 1992) in lamina II

In conclusion, dorsal root section is a poor trigger for GAP43 upregulation in the axotomized and neighboring intact DRG neurons and in deafferented dorsal horn neurons. This may explain the poor regenerative response following dorsal root injury and the absence or paucity of primary afferent collateral sprouting in the dorsal horn. A key component for axonal growth in adult neurons may be, therefore, the induction of an intrinsic growth capacity, something that peripheral axotomy does for primary sensory neurons.

\section{References}

Aigner L, Caroni P (1993) Depletion of 43-kD growth-associated protein in primary sensory neurons leads to diminished formation and spreading of growth cones. J Cell Biol 123:417-429.

Anderson PN, Chong MS, Woolf CJ, Emson PC (1992a) GAP-43 and lumbar dorsal root regeneration into long peripheral nerve grafts in rats. Neurosci Lett [Suppl] 42:S12.

Anderson PN, Chong MS, Woolf CJ, Turmaine M, Price S (1992b) The effects of a sciatic nerve lesion on lumbar dorsal root regeneration into long peripheral nerve grafts in rats. J Anat 81:360.

Benowitz LI, Lewis ER (1983) Increased transport of 4400-4900 dalton acidic proteins during regeneration of the goldfish optic nerve: a 2-dimcnsional analysis. J Ncurosci 3:2153-2163.

Benowitz LI, Routtenberg A (1987) A membrane phosphoprotein associated with neural development, axonal regeneration, phospholipid metabolism and synaptic plasticity. Trends Neurosci 10:527531 .

Benowitz LI, Apostolides PJ, Perrone-Bizzozero NI, Finkelstein SP, Zweirs $H$ (1988) Anatomical distribution of the growth-associated protein GAP-43/B-50 in the adult rat brain. J Neurosci 8:339-352.

Benowitz LI, Rodriguez WR, Neve RL (1990) The pattern of GAP43 immunostaining changes in the rat hippocampal formation during reactive synaptogenesis. Mol Brain Res 8:17-23. 
Biffo S, Verhaagen J, Shrama I.H, Schotman P, Danho W, Margolis FI. (1990) B-50/GAP-43 expression correlates with process outgrowth in the embryonic mouse nervous system. Eur J Neurosci 2:487-499.

Bisby MA (1988) Dependence of GAP-43 (B50,Fl) transport on axonal regeneration in rat dorsal root ganglion neurons. Brain Res 458: $157-161$.

Carlstedt T (1985) Regenerating axons form terminals at astrocyles. Brain Res 347:188-191.

Castro-Lopes JM, Coimbra A, Grant G, Arvidsson J (1991) Ultrastructural changes of the central scalloped (Cl) primary afferent endings of synaptic glomeruli in the substantia gelatinosa Rolandi of the rat after peripheral neurotomy. J Neurocytol 19:329-337.

Chirgwin JM, Przybyla AE, Macdonald RJ, Rutter WJ (1979) Isolation of a biologically active ribonucleic acid from sources enriched in ribonuclease. Biochemistry 18:5294-5299.

Chong MS, Fitzgerald M, Winter J, Hu-Tsai M, Emson PC, Wiese U, Woolf CJ (1992) GAP-43 mRNA in rat spinal cord and dorsal root ganglia neurons: developmental changes and re-expression following peripheral nerve injury. Eur J Neurosci 4:883-895.

Chung K, McNeil DL, Hulsebosch CE, Coggeshall RE (1989) Changes in dorsal horn synaptic disc numbers following unilateral dorsal rhizotomy. J Comp Neurol 283:568-577.

Coggeshall RE (1992) A consideration of neural counting methods. Irends Neurosci 15:9-13.

Coggeshall RE, Reynolds ML, Woolf CJ (1991) Distribution of the growth association protein GAP-43 in the central processes of axotomized primary afferents in the adult rat spinal cord; presence of growth cone-like structures. Neurosci Lett 131:37-41.

Coggins PJ, Zwiers H (1991) Biochemistry and functional neurochemistry of a neuron-specific phosphoprotein. J Neurochem 56:10951106.

Coggins PJ, McLean K, Nagy A, Zwiers H (1993) ADP-ribosylation of the neuronal phosphoprotein B-50/GAP-43. In press.

Curtis R, Stewart HJS, Hall SM, Wilkin GP, Mirsky R, Jessen KR (1992) GAP-43 is expressed by non-myelin forming Schiwann cells of the peripheral nervous system. J Cell Biol 116:1455-1464.

Czeh G, Kudo N, Kuno M (1977) Membrane properties and conduction velocity in sensory neurones following central or peripheral axotomy. J Physiol (Lond) 270:165-180.

Doster KS, Lozano AM, Aguayo AJ, Willard MA (1991) Expression of growth-associated protein GAP-43 in adult rat retinal ganglion cells following axon injury. Neuron 6:635-647.

Ernfors P, Rosario CM, Merlio J-P, Grant G, Aldskngius H, Persson H (1993) Expression of messenger RNAs for neurotrophin receptors in the dorsal root ganglion and spinal cord during development and following peripheral or central axotomy. Mol Brain Res 17:217-226.

Fawcett JW (1992) Intrinsic neuronal determinants of regeneration. Trends Neurosci 15:5-8.

Fitzgerald M, Wall PD, Goedert M, Emson PC (1985) Nerve growth factor counteracts the neurophysiological and neurochemical effects of chronic sciatic nerve section. Brain Res 332:131-141.

Fitzgerald M, Reynolds ML, Benowitz LI (1991) GAP-43 expression in the developing rat lumbar spinal cord. Neuroscience 41:187-199.

Gold BG, Mobley WC, Matheson SF (1991) Regulation of axonal caliber, neurofilament content and nuclear localization in mature sensory neurons by nerve growth factor. J Neurosci 11:943-955.

Goldherger MF, Murray M (1982) Tack of spronting and its presence after lesions of the cat spinal cord. Brain Res 241:227-239.

Greenberg SG, Lasek RJ (1988) Neurofilament protein synthesis in DRG neurons decrease more after peripheral axotomy than after central axotomy. J Neurosci 8:1739-1746.

Gundersen HJG, Bagger P, Bendtsen TF, Evans SM, Korbo L, et al. (1988) The new stereological tools: disector, fractionator, nucleator and point sampling intercepts and their use in pathological research and diagnosis. Acta Pathol Microbiol Immunol Scand 96:857-879.

Hall SM, Kent AP, Curtis R, Robertson D (1992) Electron microscopic immunocytochemistry of GAP-43 within proximal and chronically denervated distal stumps of transected peripheral nerve. J Neurocytol 21:820-831.

Hoffman PN (1989) Expression of GAP-43, a rapidly transported growth-associated protein and class II beta tubulin, a slowly transported cytoskeletal protein, are coordinated in regenerating neurons. J Neurosci 9:893-897.

Hu-Tsai M, Woolf CJ, Emson P, Winter J (1992) NGF does not regulate GAP 43 mRNA levels in adult rat dorsal root ganglion neurons. Soc Neurosci Abstr 18:418.
Jacobson RD, Virag I, Skene JHP (1986) A protein associated with axonal growth, GAP-43, is widely distributed and developmentally regulated in rat CNS. J Neurosci 6:1843-1855.

Jap Tjoen San ERA, Schmidt-Michels M, Oestreicher AB, Gispen WH, Schotman P (1992) Inhibition of nerve growth factor-induced B-50/ GAP-43 expression by antisense oligomers interferes with neurite outgrowth of PC 12 cells. Biochem Biophys Res Commun 187:839846

Kalil K, Skene JHP (1986) Elevated synthesis of an axonally transported protein correlates with axonal outgrowth in normal and injured pyramidal tracts. J Neurosci 6:2563-2570.

Karns LR, Ng S-C, Freeman JA, Fishman MC (1987) Cloning of complementary DNA for GAP-43, a neuronal growth-related protein. Science 236:597-560.

Kniyhar-Csillik E, Csillik B, Oestricher AB (1992) Light and electron microscopic localization of B-50 (GAP-43) in the rat spinal cord during transganglionic degenerative atrophy and regeneration. J Neurosci Res 32:93-109.

LaMotte CC, Kapadia SE, Kocol CE (1989) Deafferentation-induced expansion of sciatic terminal field labelling in the adult rat dorsal horn following pronase injection of the sciatic nerve. J Comp Neurol 288:311-325.

Liebermann AR (1971) The axon reaction: a review of the principal features of perikaryon responses to axon injury. Int Rev Neurobiol 14:49-124.

Lin L-H, Bock S, Carpenter K, Rose M, Norden JJ (1992) Synthesis and transport of GAP-43 in entorhinal cortex neurons and perforant pathway during lesion-induced sprouting and reactive synaptogenesis. Mol Brain Res 14:147-153.

Liu CN, Chambers WW (1958) Intraspinal sprouting of dorsal root axons. Arch Neurol Psychiatry 79:46-61.

Liuzzi FJ, Lasek RJ (1987) Astrocytes block axonal regeneration in mammals by activating the physiological stop pathway. Science 237 : 642-645.

Liuzzi FJ, Tedeschi B (1992) Axo-glial interactions at the dorsal root transitional zone regulate neurofilament protein synthesis in axotomized sensory neurons. J Neurosci 12:4783-4792.

Lu X, Kichardson PM (1992) Inflammation near the nerve cell body enhances axonal regeneration. J Neurosci 11:972-978.

McMahon SB, Kett-White R (1991) Sprouting of peripheral regenerating primary sensory neurones in the adult central nervous system. J Comp Neurol 304:307-315.

Mehta A, Reynolds ML, Woolf CJ (1993) Partial Denervation of the medial gastrocnemius muscle results in GAP-43 immunoreactivity in sprouting axons and Schwann cells. Neuroscience 57:433-442.

Meiri KF, Pfenninger KH, Willard MB (1986) Growth-associated protein, GAP-43, a polypeptide that is induced when neurons extend axons, is a component of growth cones and corresponds to pp46, a major polypeptide of a subcellular fraction enriched in growth cones. Proc Natl Acad Sci USA 83:3537-3541

Miller FD, Tetzlaff W, Bisby MA, Fawcett JW, Milner RJ (1989) Rapid induction of the major embryonic alpha tubulin mRNA T $\alpha 1$ during nerve regeneration in adult rats. J Neurosci 9:1452-1463.

Murray M, Golberger M (1986) Replacement of synaptic terminals in lamina II and Clarke's nucleus after unilateral lumbosacral dorsal rhizotomy in adult cats. J Neurosci 6:3205-3217.

Neve RL, Perrone-Bizzozero NI, Finklestein SP, Zwiers H, Bird E, Kurnit DM, Benowitz LI (1987) The neuronal growth-associated protein GAP-43 (B-50, F1): neuronal specificity, developmental regulation and regional distribution of the human and rat mRNAs. Mol Brain Res 2:177-183.

Oblinger MM, Lasek RJ (1984) A conditioning lesion of the peripheral axons of dorsal root ganglion cells accelerates regeneration of only their peripheral axons. J Neurosci 4:1736-1744.

Perkins CS, Carlstedt T, Mizuno K, Aguayo AJ (1980) Failure of regenerating dorsal root axons to regrow into the spinal cord. Can $J$ Neurol Sci 7:323

Pubols LM, Bowen DC (1988) Lack of central sprouting of primary afferent fibres after ricin deafferentation. J Comp Neurol 275:282287

Reh TA, Redshaw JD, Bisby M (1987) Axons of the pyramidal tract do not increase their transport of growth-associated proteins after axotomy. Mol Brain Res 2:1-6.

Rich KM, Luszczynski JR, Osborne PA, Johnson EM Jr (1987) Nerve growth factor protects adult sensory neurons from cell death and atrophy caused by nerve injury. J Neurocytol 16:261-268. 
Richardson PM, Issa VMK (1984) Peripheral nerve injury enhances central regeneration of primary sensory neurones. Nature 309:791793.

Richardson PM, Verge VMK (1987) Axonal regeneration in dorsal spinal roots is accelerated by peripheral axonal transection. Brain Res 411:406-408.

Rodin BA, Sampogna SL, Kruger L (1983) An examination of intraspinal sprouting in dorsal root axons with the tracer horseradish peroxidase. J Comp Neurol 215:187-198.

Schreyer DJ, Skene JHP (1991) Fate of GAP-43 in ascending spinal axons of DRG neurons after peripheral nerve injury: delayed accumulation and correlation with regenerative potential. J Neurosci 11: 3738-3751.

Schwab ME (1990) Myelin-associated inhibitors of neurite growth and regeneration in the CNS. Trends Neurosci 13:452-456.

Shea TB, Perrone-Bizzozero NI, Beermann ML, Benowitz LI (1991) Phospholipid-mediated delivery of anti-GAP-43 antibodies into neuroblastoma cells prevents neuritogenesis. J Neurosci 11:1685-1690.

Shortland P, Woolf CJ (1993) Chronic peripheral nerve section results in a rearrangement of the central terminals of axotomized $A$ beta primary afferent neurons in the rat spinal cord. J Comp Neurol 330: $65-82$.

Siegal JD, Kliot M, Smith GM, Silver J (1990) A comparison of the regenerating potential of dorsal root fibers into grey or white matter of the adult rat spinal cord. Exp Neurol 109:90-97.

Skene JHP (1989) Axonal growth-associated proteins. Annu Rev Neurosci 12:127-156.

Skene JHP, Virag I (1989) Post-translational membrane attachment and dynamic fatty acylation of a neuronal growth cone protein, GAP43. J Cell Biol 108:613-624.

Skene JHP, Willard M (1981) Axonally transported proteins associated with axon growth in rabbit central and peripheral nervous system. J Cell Biol 89:96-103.

Skene JHP, Jacobson RD, Snipes GJ, McGurie CB, Norden JJ, Freeman JA (1986) A protein induced during nerve growth (GAP-43) is a major component of growth cone membranes. Science 233:783-786.

Sommervaille T, Reynolds ML, Woolf CJ (1991) Time-dependent differences in the increase in GAP-43 expression in dorsal root ganglion cells after peripheral axotomy. Neuroscience.

Stensaas LJ, Partlow LM, Burgess PR, Horch KW (1987) Inhibition of regeneration: the ultrastructure of reactive astrocytes and abortive axon terminals in the transitional zone of the dorsal root. Prog Brain Res 71:457-467.

Suh YS, Chung K, Coggeshall RE (1984) A study of axonal diameters and areas in lumbosacral roots and nerves in the rat. J Comp Neurol 222:473-481.

Tetzlaff W, Zwiers $\mathrm{H}$, Lederis $\mathrm{K}$, Cassar $\mathrm{L}$, Richardson P, Bisby MA (1989) Axonal transport and localization of B-50/GAP-43-like immunoreactivity in regenerating sciatic and facial nerves of the rat. $\mathrm{J}$ Neurosci 9:1303-1313.

Tetzlaff W, Alexander SW, Miller FD, Bisby MA (1991) Response of facial and rubrospinal neurons to axotomy: changes in mRNA ex- pression for cytoskeletal proteins and GAP-43. J Neurosci 11:25282544.

Van der Zee CEEM, Nielander HB, Vos JP, da Silva SL, Verhaagen J, Oestreicher AB, Schrama LH, Schotman P, Gispen WH (1989) Expression of growth-associated protein B-50 (GAP43) in dorsal root ganglia and sciatic nerve during regenerative sprouting. $J$ Neurosci 9:3505-3512.

Verge VM, TetzlaffW, Richardson PM, Bisby MA (1990a) Correlation between GAP43 and nerve growth factor receptors in rat sensory neurons. J Neurosci 10:926-934.

Verge VM, Tetzlaff W, Bisby MA, Richardson PM (1990b) Influence of nerve growth factor on neurofilament gene expression in mature primary sensory neurons. J Neurosci 10:2018-2025.

Verge VMK, Merlio J-P, Grondin J, Ernfors P, Persson H, Riopelle RJ, Hökfelt T, Richardson PM (1993) Co-localization of nerve growth factor receptor mRNA in primary sensory neurons: responses to injury, and infusion by nerve growth factors. J Neurosci 12:401 I -4022 .

Widmer F, Caroni P (1993) Phosphorylation-site mutagenesis of the growth-associated protein GAP-43 modulates its effects on cell spreading and morphology. J Cell Biol 120:503-512.

Wiese UH, Ruth JL, Emson PC (1992) Differential expression of growth-associated protein (GAP-43) mRNA in rat primary sensory neurons after peripheral nerve lesion: a non-radioactive in situ hybridization study. Brain Kes 492:141-156.

Wong J, Oblinger MM (1990) A comparison of peripheral and central axotomy effects on neurofilament and tubulin gene expression in rat dorsal root ganglion neurons. J Neurosci 10:2215-2222.

Wong J, Oblinger MM (1991) NGF rescues Substance P expression but not neurofilament or tubulin gene expression in axotomized sensory neurons. J Neurosci 11:543-552.

Woolf CJ, Reynolds M, Molander C, O'Brien C, Lindsay RM, Benowitz LI (1990) GAP-43 appears in the rat dorsal horn following peripheral nerve injury. Neuroscience 34:465-478.

Woolf CJ, Shortland P, Coggeshall RE (1992a) Peripheral nerve injury triggers central sprouting of myelinated afferents. Nature 355:75-78.

Woolf CJ, Reynolds ML, Chong MS, Emson P, Irwin N, Benowitz LI (1992b) Denervation of the motor endplate results in the rapid expression by terminal Schwann cells of the growth associated protein GAP-43. J Neurosci 12:3999-4010.

Wujek JR, Lasek RJ (1983) Correlation of axonal regeneration and slow component $b$ in two branches of a single axon. J Neurosci 3:243 251 .

Yanker BA, Benowitz LI, Villa-Komaroff I, Neve RI, (1990) Transfection of PC12 cells with the human GAP-43 gene: effects on neurite outgrowth and regeneration. Mol Brain Res 7:39-44.

Zuber MX, Goodman DW, Karns LR, Fishman MC (1989) The neuronal growth-associated protein GAP-43 induces filopodia in nonneuronal cells. Science 244:1193-1195.

Zwiers H, Verhaagen J, Van Dungen CJ, De Graan PNE, Gispen WH (1985) Resolution of rat brain synaptic phosphoprotein B-50 into multiple forms by two-dimensional electrophoresis: evidence for multiple phosphorylation. J Neurochem 44:1083-1090. 